\title{
Identifikasi Citra Susu Formula Dengan Learning Vector Quantization Untuk Mengenali Susu Basi
}

\section{Identification of Formula Milk Image with Learning Vector Quantization to Recognize Stale Milk}

\author{
Yulisda Nandasari ${ }^{1}$, Supatman ${ }^{2}$ \\ ${ }^{1,2}$ Program Studi Teknik Informatika, Fakultas Teknologi Informasi, Universitas Mercu Buana Yogyakarta, \\ J1. Wates Km. 10 Yogyakarta 55753, Indonesia \\ Email: ${ }^{1}$ yulisdanandasari1@gmail.com, ${ }^{2}$ supatman@mercubuana-yogya.ac.id
}

\begin{abstract}
ABSTRAK
Susu merupakan sumber protein utama pada balita karena memiliki nilai gizi yang tinggi. Pada saat ini terjadi perubahan kebiasaan konsumsi masyarakat yang dahulu adalah air susu ibu (ASI) sekarang bergeser ke susu formula. Beralihnya ke konsumsi susu formula dikarenakan mudahnya dalam penyajian dan dapat diberikan kepada balita di tempat umum. Susu formula yang telah dibuat memiliki waktu tertentu untuk dapat dikonsumsi, sebagian masyarakat terlena apakah susu formula yang dibuat masih layak konsumsi atau sudah basi. Secara kasat mata susu yang telah basi dapat diamati secara inderawi melalui vision, sehingga citra susu basi dapat dianalisa dan diidentifikasi menggunakan pengolahan citra digital dan jaringan syaraf tiruan. Tujuan penelitian ini pengembangan algoritma untuk mengidentifikasi susu formula kadaluarsa, menggunakan Learning Vector Quantization (LVQ) dengan pendekatan warna. Pada proses pelatihan diperoleh unjuk kerja terbaik sebesar 97,77\%, untuk kelas satu (susu fomula baru dibuat) $100 \%$, kelas dua (susu formula didiamkan satu setengah jam) 96,66\% dan kelas tiga (susu formula basi) $96,66 \%$ yaitu pada $\alpha 0,001$ dengan dec $\alpha 0,9$. Bobot akhir pelatihan tersebut digunakan pada pengenalan 60 data uji dengan unjukkerja komulatif tertinggi $97,77 \%$.
\end{abstract}

Kata Kunci : Histogram, Learning Vector Quantization (LVQ), Susu Formula.

\begin{abstract}
Milk is the main source of protein in infants because it has a high nutritional value. At this time there is a change in consumption habits of people who used to consume breast milk now shifting to formula milk. The switch to consumption of formula milk is because it is easy to serve and can be given to toddlers in public places. Formula milk that has been made has a certain time to be consumed, some people are complacent whether the formula milk that is made is still suitable for consumption or already stale. In plain view, stale milk can be sensually observed through vision, so that stale milk images can be analyzed and identified using digital image processing and artificial neural networks. The purpose of this study was to develop an algorithm to identify expired formula milk, using Learning Vector Quantization (LVQ) with a color approach. In the training process, the best performance was 97.77\%, for first grade (freshly made milk) 100\%, second class (formula milk left for one and a half hours) $96.66 \%$ and third grade (stale formula milk) $96.66 \%$ ie at $\alpha 0,001$ with dec $\alpha 0$,9. The final weight of the training was used in the introduction of 60 test data with the highest cumulative performance of $97.77 \%$.
\end{abstract}

Keywords : Formula milk, Histogram, Learning Vector Quantization (LVQ).

\section{PENDAHULUAN}

Susu merupakan sumber protein yang sangat dibutuhkan pada balita karena memiliki nilai gizi yang tinggi. Pada saat ini terjadi perubahan kebiasaan konsumsi masyarakat yang semula air susu ibu (ASI) bergeser ke susu formula. Beralihnya ke konsumsi susu formula dikarenakan mudahnya dalam penyajian dan dapat diberikan kepada balita di tempat umum.

Susu formula adalah minuman yang cepat basi. Jika susu formula basi susu sudah 
terkontaminasi oleh kuman, bakteri, virus dan parasit yang bisa menyebabkan keracunan. Gejala keracunan makanan atau minuman yaitu mual, muntah, diare, nyeri perut dan rewel. Ciri susu yang sudah basi adalah berbau tengik, berubah warna tidak kuning cerah dan terdapat gumpalan.

\section{TINJAUAN PUSTAKA}

Dalam penelitan dengan judul “ Identifikasi tekstur citra bubuk susu menggunakan alihragam gelombang singkat untuk mendeteksi keaslian produk susu", dalam penelitian ini yang berjudul identifikasi citra susububuk menggunakan alihragam gelombang singkat untuk mendeteksi keaslian produk susu . Aplikasi ini dirancang untuk dapat meng identifikasi produk susu bubuk yang dipandang sebagai tekstur dalam citra digital. (Supatman, 2008).

Dalam penelitan dengan judul "Sistem intelijen prediksi dan penilaian kualitas susu pasteurisasi dengan menggunakan logika fuzzy dan jaringan syaraf tiruan", dalam penelitian ini sistem kontrol kualitas dioprasiakan dalam dua bagian yaitu dimensi kualitas produk seperti performansi, feature, keandalan, konformasi, durability, estetika, kualitas yang dirasakan oleh konsumen dan menentukan suhu pasteurisasi.Sistem diimplementasikn dengan fuzzy inference system (FIS) dan jaringan syaraf tiruan (Winnie Septani \&Marimin, 2005).

\subsection{LANDASAN TEORI}

\subsubsection{Susu Formula}

Susu formula adalah susu cair atau bubuk dengan komposisi tertentu unuk bayi atau anak yang berfungsi sebagai pengganti air susu ibu (ASI). Alasan dipakai susu sapi sebagai bahan dasar karena banyaknya susu yang dapat dihasilkan oleh peternak (Pudjadi, 2000).

\subsubsection{Citra Digital}

Citra adalah suatu representasi (gambar), imitasi atau kemiripan dari suatu objek. Citra terdiri dari 2 yaitu ada citra bersifat analog dan citra bersifat digital. Citra analog merupakan citra yang bersifat kontinyu sebagaimana gambar di monitor televisi, foto sinar X, hasil CTscan dan lain-lain. Sedangkan citra digital merupakan citra memungkinkan diolah oleh komputer (Sutoyo, 2009).

\subsubsection{Pra-proses}

Pra-proses

merupakan proses pengolahan citra asli sebelum citra tersebut diproses lebih lanjut. Beberapa pra-proses yang biasa digunakan yaitu proses pengambilan ROI (Reference of Interest) dan proses keabuhan (grayscale). Proses pengambilan ROI merupakan proses pengambilan citra pada daerah tertentu pada citra. Proses ini digunakan untuk mengambil bagian penting atau area tertentu yang mempunyai lebih banyak informasi pada proses selanjutnya pada jaringan syaraf tiruan.

\subsubsection{Histogram Citra}

Histogram citra merupakan grafik yang memperlihatkan frekuensi kemunculan pada tiap nilai gradasi warna. Misalkan citra digital yang dimiliki L derajat grey, yaitu rentang nilai 0 sampai L-1 (misalnya citra dengan kuantisasi keabuan 8-bit, nilai derajat grey dari 0 hingga 255) (Sutoyo, 2009).

\subsubsection{Jaringan Syaraf Tiruan}

Jaringan syaraf tiruan merupakan salah satu representasi buatan dari otak manusia yang selalu mencoba menstimulasi proses pembelajaran pada otak manusia tersebut. Jaringan syaraf tiruan dapat digambarkan sebagai model matematis dan komputasi untuk fungsi aproksimasi non-linear, klasifikasi data cluster dan regresi non-parametrik atau sebuah simulasi dari koleksi model jaringan syaraf biologi. Hal lain yang penting adalah proses belajar hubungan input/output dilakukan dengan pembelajaran (Purnama, 2016).

\subsubsection{Metode Learning Vector Quantiztion}

Learning Vector Quantization (LVQ) adalah suatu metode pada pembelajaran pada lapisan kompetitif supervised. Pada lapisan kompetitif akan secara otomatis melakukan pembelajaran untuk mengklasifikasikan vektor-vektor masukkan. Kelas yang diperoleh sebagai hasil dari lapisan kompetitif ini terbatas tergantung pada jarak antara vektorvektor masukkan. Algoritma ini bertujuan mendekati distribusi kelas vektor untuk meminimalkan kesalahan dalam pengklasifikasian (Kusumadewi, 2003).

Arsitektur algoritma Learning Vector Quantization ditunjukkan pada Gambar 1. 


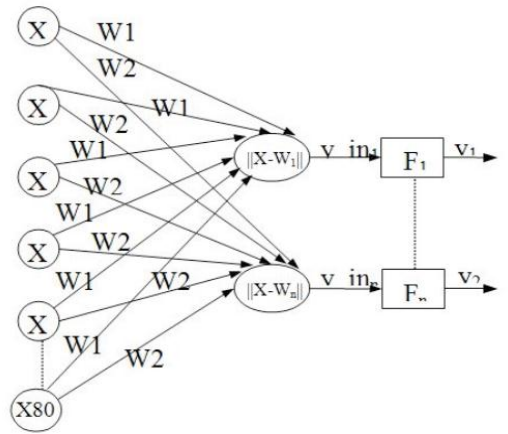

Gambar 1. Arsitektur Learning Vector Quantization (Qur'ani \& Rosmalinda, 2010)

\section{METODOLOGI PENELITIAN}

\subsection{Bahan Penelitian}

Bahan atau objek citra yang digunakan dalam melakukan penelitian ini adalah Susu formula yang telah disajikan untuk mengetahui kelayakan.

\subsection{Desain Sistem}

Desain dalam penelitian identifikasi susu formula ini ditunjukkan pada Gambar 2.

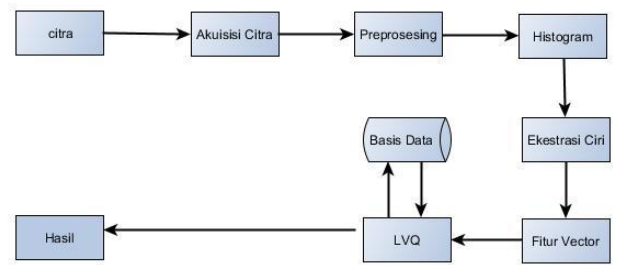

Gambar 2. Desain Sistem Identitifikasi susu formula.

\subsubsection{Akuisisi Data}

Akuisisi data merupakan tahap pertama yang dilakukan dalam proses identifikasi citra susu formula. Alat yang dipakai untuk pengambilan gambar adalah kamera. Pengambilan dilakukan dengan jarak 20-23 cm vertikal ke atas. Pengambilan citra susu formula yang diupayakan memiliki pencahayaan yang cukup, fokus dan jarak pengambilan yang sama.

\subsubsection{Data}

Data hasil dari akuisisi merupakan data yang berupa citra dari susu formula. Citra susu formula dari hasil akuisisi akan digunakan pada pemrosesan tahap selanjutnya.

\subsubsection{Pra-Proses}

Tahapan pra-proses meliputi cropping ROI dan konversi skala keabuhan (grey). Cropping ROI merupakan teknik pemotongan citra yang digunakan untuk menentukan secara tepat bagian yang ingin diolah. Cropping ROI bertujuan untuk mempermudah analisis citra dan memperkecil penyimpanan citra. Pada proses cropping ROI dilakukan dengan cara memotong ukuran citra pada ukuran 200x200 piksel, sehingga proses komputasi pada tahap selanjutnya diharapkan lebih cepat.

Proses konversi dari citra warna ke level keabuhan ditunjukkan pada Gambar 3.

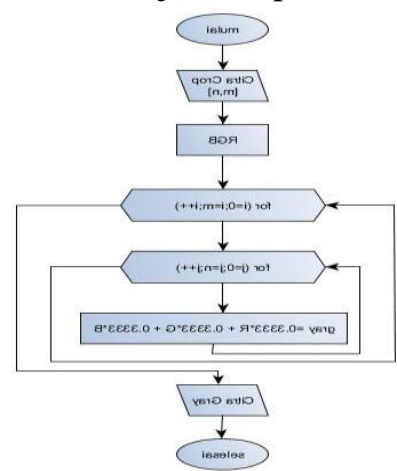

\section{Gambar 3. Diagram Alir Grayscale}

\subsubsection{Histogram}

Setelah pra-proses dilakukan tahap selanjutnya yaitu proses histogram citra. Citra yang sudah menjadi keabuhan diproses untuk menentukan komposisi ke dalam grafik derajat keabuan . Histogram merepresentasikan distribusi jumlah piksel untuk tiap intensitas warna dalam citra. Diagram alir histogram citra ditunjukkan pada Gambar 4.

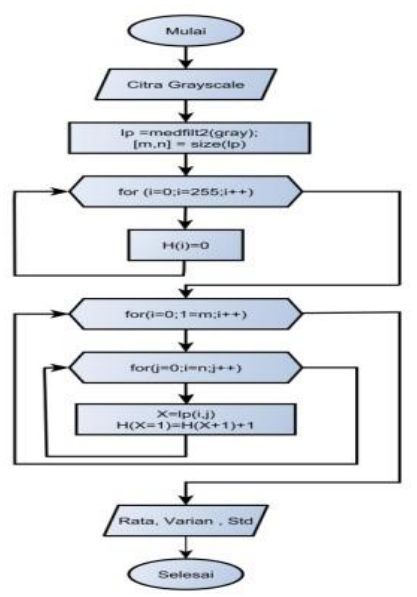

Gambar 4. Diagram Alir Histogram Citra.

\subsubsection{Ekstraksi Ciri}

Ekstraksi ciri dillakukan untuk pengambilan ciri / feature dari objek citra susu, ciri yang diperoleh digunakan sebagai variabel/parameter untuk membedakan antara citra objek susu yang satu dengan lainnya pada tahapan-tahap identifikasi citra susu. Proses ini 
dilakukan untuk kuantisasi karakteristik citra ke dalam kelas nilai ciri yang sesuai. Sehingga mendapatkan informasi kuantitatif ciri yang dapat membedakan kelas-kelas objek susu. Dalam penelitian ini digunakan 3 ciri adalah rata-rata, varian, dan standar deviasi (std).

\subsubsection{Fitur Vektor}

Fitur vektor ciri dari hasil masingmasing ciri tersebut disimpan dalam database untuk digunakan sebagai database pengetahuan untuk proses pelatihan dan identifikasi.

\subsubsection{Learning Vector Quantization}

Learning Vector Quantization merupakan sebuah metode klasifikasi yang mana setiap unit output mempresentasikan sebuah kelas. Tiga kelas pada identifikasi susu basi ini terdiri dari : kelas satu (susu formula baru), kelas dua (susu formula satu setengah jam) dan kelas ketiga (susu formula basi). Berikut adalah algoritma Learning Vector Quantization ditunjukkan pada Gambar 5 dan Gambar 6.

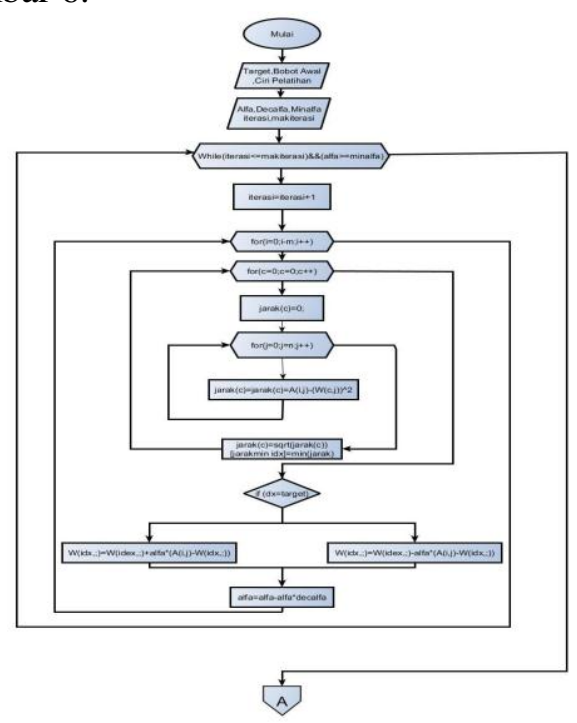

Gambar 5. Algoritma Learning dari $L V Q$ untuk Identifikasi Susu Formula.

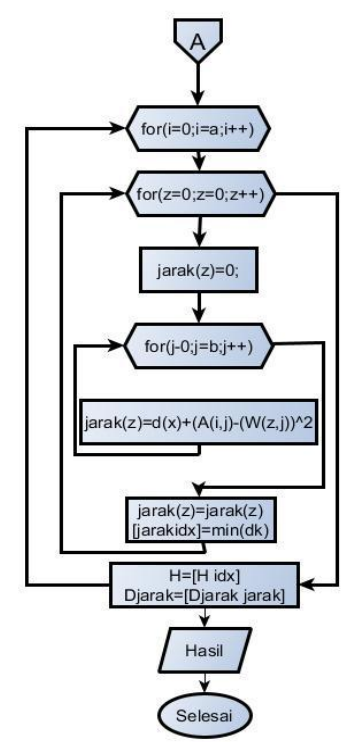

Gambar 6. Algoritma Identifikasi dari $L V Q$ pada Identifikasi Susu Formula.

\section{PEMBAHASAN}

\subsection{Data Citra Susu}

Data citra susu hasil akuisi susu formula dengan Kamera Digital Casio EX-ZS6 dan disimpan dalam format jpg dengan dimensi 2500 x 2500 piksel ditunjukkan pada Gambar 7.

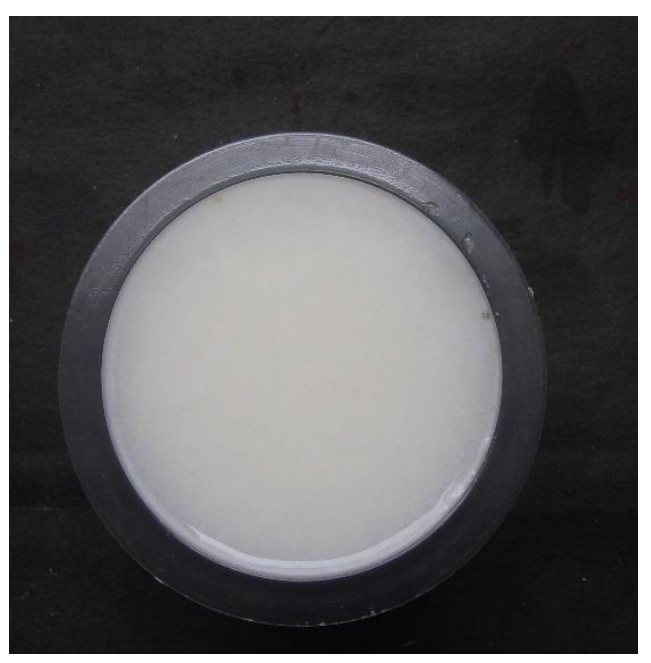

Gambar 7. Data Citra 2500 x 2500 piksel hasil akusisi susu formula dengan kamera digital Casio EX-ZS6

\subsection{Pra-Proses Citra Susu}

Citra susu hasil dari proses akuisi diambil ROI ukuran 200 x 200 piksel, untuk Citra susu formula yang baru dibuat, citra susu formula satu setengah jam dan susu formula basi ditunjukkan pada Gambar 8 . 


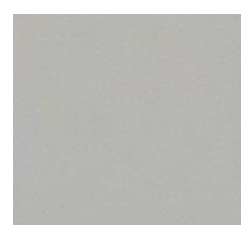

(a)

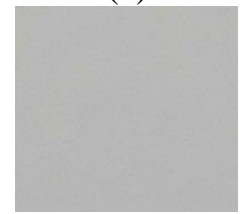

(b)

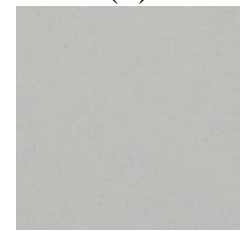

(c)

Gambar 7. Data citra susu formula (a). Susu formula baru, (b). Susu formula satu setengah jam, (c). Susu Basi

\subsection{Histrogram Citra Susu}

Histogram citra susu diperoleh dari histogram citra keabuan dari citra ROI, ditunjukkan pada Gambar 8 dan Gambar 9.

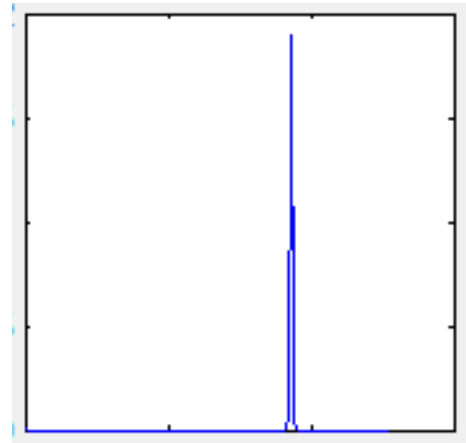

Gambar 8. Histogram Cita Susu formula baru.

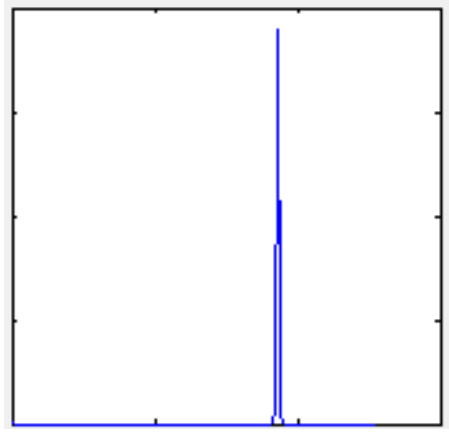

(a)

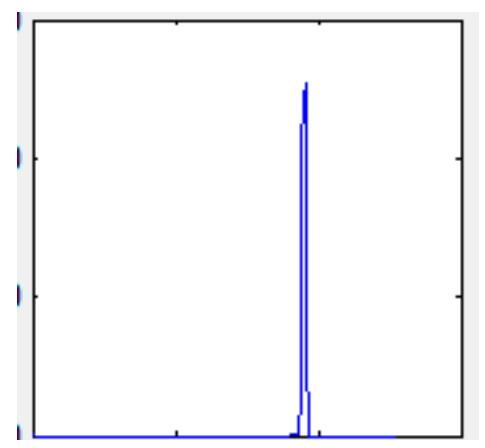

(b)

Gambar 9. Histogram (a). Susu formula satu setengah jam, (b). Susu formula basi

Gambar 8, dan Gambar 9.(a), 9(b) memperlihatkan hitogram citra yang hampir mirip. Pola histogram susu formula baru dan susu formula satu setengah jam secara visual memperlihatkan kemiripan bentuk/pola. Sedangkan untuk histogram susu formula basi memperlihatkan dasar histogram yang agak besar dari pada histogram susu formula baru dan susu formula satu setengah jam.

\subsection{Ekstrasi Ciri Citra Susu}

Ekstrasi untuk citra susu dilakukan dengan mengekstrak ciri yaitu rata-rata, standar deviasi dan varian. Hasil ekstraksi ciri untuk histogram citra susu formula baru, satu setengah jam dan basi ditunjukan pada Tabel 1 .

Tabel 1. Hasil ekstrasi ciri citra susu formula untuk ciri rata-rata, varian dan standar deviasi

\begin{tabular}{clccc}
\hline No & $\begin{array}{c}\text { Citra } \\
\text { Susu }\end{array}$ & $\begin{array}{c}\text { Rata- } \\
\text { rata }\end{array}$ & $\begin{array}{c}\text { Ciri } \\
\text { Varian }\end{array}$ & $\begin{array}{c}\text { Standar } \\
\text { Deviasi }\end{array}$ \\
\hline 1 & Baru & 190.9084 & $1.2331 \mathrm{e}+04$ & 111.0471 \\
2 & $\begin{array}{l}\text { Satu } \\
\text { setengah }\end{array}$ & 237.9763 & $3.9878 \mathrm{e}+04$ & 199.6960 \\
& jam & & & \\
3 & Basi & 205.2311 & $3.0960 \mathrm{e}+04$ & 175.9545 \\
\hline
\end{tabular}

Berdasarkan Tabel 1. Ciri untuk citra susu formula baru memiliki rata-rata 190,9084 varian $1,2331 \mathrm{e}+04$ dan standar deviasi 111,0471. Citra susu formula satu setengah jam memiliki rata-rata 237,9763 varian 3,9878e+04 dan standar deviasi 199,6960. Sedangkan citra susu formula basi rata-rata 205,2311 varian $3,0960 \mathrm{e}+04$ dan standar deviasi 175,9545.

Ciri rata-rata untuk susu formula baru, susu formula satu setengah jam dan susu 
formula basi secara berturut-turut 190,9084 , 237,9763 dan 205,2311. Hal ini terlihat bahwa nilai rata-rata untuk susu formula basi berada di antara susu formula baru dan susu formula satu setengah jam.

Ciri varian untuk susu formula baru, susu formula satu setengah jam dan susu formula basi secara berturut-turut 1,2331e+04 $3,9878 \mathrm{e}+04$ dan 3,0960e+04. Hal ini terlihat juga bahwa nilai varian untuk susu formula basi berada di antara susu formula baru dan susu formula satu setengah jam.

Sedangkan untuk ciri standar deviasi susu formula satu setengah jam dan susu formula basi secara berturut-turut 111,0471, 199,6960 dan 175,9545. Hal ini terlihat juga bahwa nilai standar deviasi untuk susu formula basi berada di antara susu formula baru dan susu formula satu setengah jam.

Sehingga berdasarkan ketiga variabel ciri dan tiga data dapat dinyatakan bahwa ciri (rata-rata, varian dan standar devisasi untuk citra susu formula basi berada diantara citra susu formula baru dan citra susu fromula satu setengah jam.

\subsection{Fitur Vektor}

Fitur vektor merupakan pola dari susu formula baru, susu formula satu setengah jam dan susu formula basi ditunjukkan pada Tabel 2 .

Tabel 2. Fitur vektor susu formula baru, susu formula satu setengah jam dan susu formula basi

\begin{tabular}{|c|c|c|}
\hline No & Citra Susu & Fitur Vektor \\
\hline 1 & Baru & $\begin{array}{c}{[190,9084 \quad 1,2331 \mathrm{e}+04} \\
111,0471]\end{array}$ \\
\hline 2 & $\begin{array}{l}\text { Satu } \\
\text { setengah } \\
\text { jam }\end{array}$ & $\begin{array}{c}{[237,9763 \quad 3,9878 \mathrm{e}+04} \\
199,6960]\end{array}$ \\
\hline 3 & Basi & $\begin{array}{c}{[205,2311 \quad 3,0960 \mathrm{e}+04} \\
175,9545]\end{array}$ \\
\hline
\end{tabular}

Berdasarkan Tabel 2, pola atau fitur vektor susu formula basi berada pada aras tengah dari susu formula baru dan susu formula satu setengah jam. Hal ini menunjukan bahwa pola susu formula basi berada pada skala tengah atau nilai tengah antara susu formula baru dan susu formula satu setengah jam.

\subsection{Unjukkerja Pelatihan dan Identifikasi.}

Pelatihan LVQ dalam menyiapkan pola pengetahuan yang digunakan pada proses identifikasi digunakan parameter pelatihan ditunjukan pada Tabel 3.

Tabel 3. Parameter Pelatihan LVQ untuk Identifikasi Susu formula.

\begin{tabular}{ll}
\multicolumn{1}{c}{ Parameter } & \multicolumn{1}{c}{ Nilai } \\
\hline Jumlah Data Pelatihan & 90 \\
Jumlah Data uji & 60 \\
Jumlah Pola Target & 3 \\
Variasi Laju Pelatihan $(\alpha)$ & 0,$1 ; 0,01 ;$ \\
Update Laju Pelatihan & 0,$001 ;$ \\
Variasi Penurunan Laju & $\alpha=\alpha-\alpha(\operatorname{dec} \alpha)$ \\
Pelatihan (dec $\alpha)$ & 0,$7 ; 0,5 ; 0,6 ; 0,9$ \\
Minimum Laju Pelatihan & 0,000001 \\
yang Diharapkan & 1000 \\
Maksimum Iterasi & \\
\hline
\end{tabular}

Hasil unjuk kerja pelatihan identifikasi susu formula ditunjukan pada Tabel 4 dan Gambar 10.

Tabel 4. Unjuk Kerja Pelatihan Identifikasi

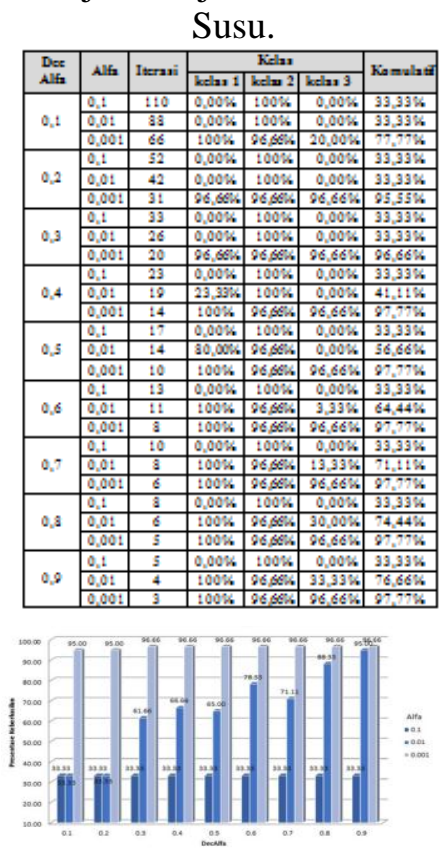

Gambar 10. Grafik Kinerja Pelatihan Identifikasi Susu.

Basis pengetahuan yang diperoleh dari proses pelatihan dengan data latih digunakan untuk prose identifikasi susu formula dengan unjuk kerja ditunjukan pada Tabel 5 dan Gambar 11. 
Tabel 5. Pengenalan Data Uji Identifikasi susu formula.
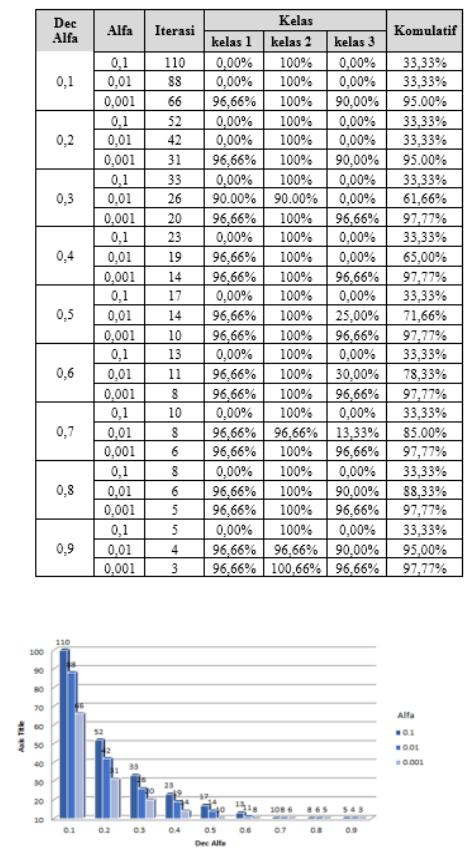

Gambar 11. Grafik Kinerja Identifikasi.

Berdasarkan Tabel 4, Gambar 10 merupakan tabel pelatihan dengan 90 data latih. Unjukkerja komulatif tertinggi pada pelatihan adalah $97,77 \%$ pada $\alpha 0.001$ dan $d e c$ $\alpha$ 0,9. Sedangkan perincian dari $97,77 \%$ adalah unjukkerja susu formula baru sebesar $100 \%$, susu formula satu setengah sebesar $96,66 \%$ dan susu fomula basi sebesar 96,66\%. Sehingga pelatihan untuk susu formula yang baru dibuat telah dilatih hingga memiliki kemampuan identifikasi dengan data latih sebesar $100 \%$. Untuk susu formula satu setengah dan susu formula basi memiliki unjukkerja pelatihan sebesar 96,66\%, sehingga ada faktor kegagalan sebesar 3,34\%.

Sedang pada pengujian identifikasi dengan 60 data uji ditunjukan pada Tabel 5 dan Gambar 11 dengan unjukkerja identifikasi komulatif tertinggi yaitu sebesar $97,77 \%$. Hasil pengujian identifikasi susu formula tertinggi pada susu formula satu setengah jam dengan unjukkerja $100 \%$, sedangkan susu formula baru dan susu formula basi masing-masing $96,66 \%$, sehingga kemungkinan ada faktor kegagalan identifikasi sebesar 3,34\%.

\section{KESIMPULAN}

Kesimpulan dari penelitian identifikasi citra susu formula menggunakan metode $L V Q$ untuk mengenali susu kadaluarsa, berdasarkan data uji dengan 60 data, yang terdiri dari 20 data kelas 1 (susu formula yang baru saja dibuat) dan 20 data kelas 2 (susu formula yang sudah di diamkan satu setengah jam ) dan 20 data kelas 3 (susu formula yang lebih dari dua jam) diperoleh unjuk kerja pelatihan sebesar $97,77 \%$ untuk kelas satu 96,66\%, kelas dua $100 \%$ dan kelas tiga $96,66 \%$.

\section{DAFTAR PUSTAKA}

Afriandi, E., \& Sutikno. (2016). Identifikasi Telapak Tangan Menggunakan Jaringan Syaraf Tiruan Learning Vector Quantization (LVQ). Jurnal Infotel, Vol. 8, No.2, ISSN : 20853688, Hal. 107-114.

Arifin, J., \& Naf'an, M. Z. (2017). Verifikasi Tanda Tangan Asli Atau Palsu Berdasarkan Sifat Keacakan (Entropi). Jurnal Infotel, Vol.9, No.1, ISSN : 2085-3688, Hal. 130-135.

Arippin, J. N., Sutresno, A., \& Rondonuwu, F. S. (2014). Identifikasi Susu Sapi Murni Dan Susu Sapi Yang Mengandung Peroksida Dengan Spektroskopi Inframerah Dekat Dengan Teknik PCA. Prosiding Seminar Nasional Sains Dan Pendidikan Sains IX, Fakultas Sains Dan Matematika, UKSW, Vol.5, No.1, ISSN : 2087-0922, Hal. 193-196.

Catur, S. (2007). Permintaan Gula di Indonesia. Jurnal Ekonomi Pembangunan, Vol.8, Fakultas Ekonomi, Universitas Gadjah Mada.

Gustina, S., Fadlil, A., \& Umar, R. (2016). Identifikasi Tanaman Kamboja menggunakan Ekstraksi Ciri Citra Daun dan Jaringan Syaraf Tiruan. Annual Research Seminar, Vol.2, No.1, ISBN : 979-587-626-0, Hal. 128132.

Hamidi, R., Furqon, M. T., \& Rahayudi, B. (2017). Implementasi Learning Vector Quantization (LVQ) untuk Klasifikasi Kualitas Air Sungai. Jurnal Pengembangan Teknologi Informasi dan Ilmu Komputer, Vol. 1, No. 12(eISSN: 2548-964X), hal. 1758-1763. 
Health, R. b. (2004). Havelarr \& Zweitering .

Hermawan. (2006). Jaringan Syaraf Tiruan Teori dan Aplikasi. Yogyakarta.

Jasril, Cahyana, M. S., Handayani, L., \& Budianita, E. (2015). Implementasi Learning Vektor Quantization (LVQ) dalam Mengidentifikasi Citra Daging Babi dan Daging Sapi. Seminar Nasional Teknologi Informasi, Komunikasi dan Industri (SNTIKI) 7, ISSN : 2085-9902, Hal. 176-184.

Jasril, Handayani, L., Budianita, E., \& Amri, F. U. (2017). Seminar Nasional Teknologi Informasi, Komunikasi dan Industri (SNTIKI) 9. ISSN (Printed) : 2579-7271 ISSN (Online) : 2579-5406, Hal. 283-292.

Kristianingrum, S. (2009). Analisis Nutrisi Dalam Gula Semut. Fakultas Matematika dan Ilmu Pengetahuan Alam. Universitas Negeri Yogyakarta.

Krstina. (2001). Pemberian ASI Eksklusif Kepada Bayi 0-4 Bulan Dan Faktor Faktor Yang Mempengaruhi Di Indonesia,. Jurnal Ilmu Kesehatan, Volume 8.

Kusumadewi, S. (2003). Artificial Intelligence : Teknik dan Aplikasinya. Yogyakarta.

Palma, B. P. (2010). Pemanfaatan Tumbuhan Palma. Manado.

Pudjadi. (2000). Ilmu Gizi Klinis Pada Anak.
Purnama, A. (2016). Jaringan Syaraf Tiruan (Neural Network). Diambil kembali dari http://elektronikadasar.web.id/jaringan-syaraf-tiruanneural-network/

Puspaningrum, D. (2006). Pengantar Jaringan Syaraf Tiruan. Yogyakarta.

Qur'ani, D. Y., \& Rosmalinda, S. (2010). Jaringan Syaraf Tiruan Learning Vector Quantization Untuk Aplikasi Pengenalan Tanda Tangan. Seminar Nasional Aplikasi Teknologi Informasi 2010, ISSN: 1907-5022, Hal. 6-10.

Sing, J. J. (2004). Jaringan Syaraf Tiruan Pemrogramannya Menggunakan MATLAB.

Sugiyanto, C. (2007). Permintaan Gula di Indonesia. Jurnal Ekonomi Pembangunan, Volume 8.

Suharsimi. (2009). Menejemen Penelitian. Jakarta: Rineka Cipta.

Supatman. (2008). Identifikasi Tekstur Citra Bubuk Susu Menggunakan Alihragam Gelombang Singkat Untuk Mendeteksi Keaslian Prodak Susu. Seminar on Intelligent Technology and Its Applications, ISBN 978-979-8897-245, Hal 386 -392.

Sutoyo, T. (2009). Teori Pengolahan Citra Digital.

Widodo, T. (2005). Sistem Neuro Fuzzy Untuk Pengolahan Informasi, Pemodelan Dan Kendali. Yogyakarta: Graha Ilmu. 